\title{
The Presence of Pesticide Residues in Select Commodities in Albanian Market
}

\author{
Sofiana Mai, Ederina Ninga, Mimoza Mukajand Magdalena Cara
}

\begin{abstract}
Widespread use of pesticides is linked to the development of agriculture in our country; however, the usage of this toxic compound must be controlled. The purpose of this study is to investigate pesticide residues in grape and lettuce samples from the Albanian market. From March to October 2017, we randomly collected 44 grapes and 34 lettuce samples from some region in Albania such as Tirana, Durres, Fier, Lushnje, Elbasan and Vlora. The collected sample underwent pesticide residue analysis, and pesticide extraction which wasperformed using ethyl acetate. Instrumental analysis was carried out in GC/MS Triple Quadrupole in multiple reactions monitoring mode. Products such as vegetables and fruits, available in our markets should be safe andcontrolled to limit potential risk to public health. In this study we concluded that no lettuce samples exceed the maximum residues level values for some pesticides, $19 \%$ of grape samples resulted above the MRL, and Chlorpyrifos is the most active substance found more than $0.05 \mathrm{mg} \mathrm{kg}^{-1}$.
\end{abstract}

Index Terms-Multi Residues Analysis; Grapes; Lettuces; GC MS/MS.

\section{INTRODUCTION}

Worldwide pesticide usage has greatly increased since the 1960s, and it has been responsible for the "green revolution", which allowed the industry to increase food production from the same land surface by means of mineral fertilizers (nitrogen, phosphorus, potassium), as well as more efficient machinery and irrigation strategies. The use of pesticides has helped reduce crop losses and increase yield of crops such as corn, maize, vegetables, potatoes and cotton [1]. Pesticides help prevent and control pests, reduce or eliminate performance losses and maintain quality of products of plants origin. The application of pesticides in plants has led to serious impacts to human health and environment. Public concern about food safety has increased due to and recognition of the effects of pesticide use such as chronic neurotoxicity, immune impacts, endocrine disruption, mutagenicity, genotoxicity, and carcinogenesis. Pesticide residues of vegetables and fruits have become a health issue around the world [2][3][4]. Directive 2009/128/EC aims to reach a sustainable use of pesticides, including guidance and advice to pesticide applicants, instructions on the operation and control of equipment to provide safety, and protection of human health and the environment [5]. The proposed MRLs are derived from supervised field trials lead on Good Agricultural Practice. To evaluate consumer safety, exposure to pesticide residues should be assessed and compared to health safety

Published on January 31, 2019

S. Mai is with the Food Safety and Veterinary Institute, Albania.
limits.Residue levels above the MRL must be analysed to determine if daily intake could exceed the health-based limits [6]. Recently, the increasing of public concern of health risk from pesticide residues, has led to strict regulation of maximum residue limits (MRL) and total dietary intake of pesticide residues in food [7].The reduction of pesticide use is one of the critical points to preserve the environment and human health. Recent study has shown that total pesticide use could be reduced by $42 \%$ without any negative effects on both productivity and economic issues [8]. Pesticide residues in Albanian in products of plant origin is a very concern topic, because of excessive use of pesticides in agriculture as well as the effects on human health and effects in environment. We conducted this study in lettuce and grape for the presence of 39 pesticide residues. The values from screening were compared with MRL of each pesticide.

\section{MATERIAL AND METHODS}

We implemented the pesticide residues analysis methodology described by Nordic Committee on Food Analysis described in their 2013 paper [9]. Samples were randomly collected from March to October 2017 from Albanian markets in different towns. Samples, exactly 44 grape samples collected from Tirana (23), Durres (2), Fier (3), Lushnje (2), Elbasan (3), Vlora (11) and 34 lettuces were collected from Tirana (31), and Vlora (3). Representative samples up to $1 \mathrm{~kg}$ were transferred immediately in the laboratory by a cool box [10]. During the preparation phase, the samples were homogenized using a blender. Samples of $10 \pm 0.02$ gram were used for further analysis. The procedure continued with the addition of 20 $\mathrm{mL}$ ethyl acetate; shake for $15 \mathrm{~min}$ in a horizontal shaker; 10 gram of sodium sulphate was added and again $10 \mathrm{~min}$ in the shaker and the last step was 5 min centrifugation at 3200 $\mathrm{rpm}$. Approximately $1 \mathrm{~mL}$ of sample extract was transferred into a $2 \mathrm{~mL}$ glass vial and finally injected in GC/MS/MS.

Reference materials used were of pesticide grade and were purchased from DR. Erhenstrofer. Stock solutions were prepared from each reference material separately diluted in acetonitrile to make $1000 \mu \mathrm{g} \mathrm{mL}-1$. Intermediate standard mixtures were prepared in ethyl acetate, containing $10 \mu \mathrm{g} \mathrm{mL}-1$ of each compound, were prepared by mixing appropriate quantities of each stock solution. $1 \mu \mathrm{g} \mathrm{mL}-1$ working standard mixture prepared from intermediate standard mixture was used for calibration curve and for quality control samples. Other chemicals for extraction such as sodium sulphate and ethyl acetate were purchased from VWR chemicals. 
TABLE I: MULTIPLE REACTION MONITORING (MRM) TRANSITIONS, COLLISION ENERGY (CE) FOR EACH TRANSITION FOR EACH ANALYZE

\begin{tabular}{|c|c|c|c|c|c|}
\hline Name & Chemical class & $\begin{array}{l}\text { Transiti } \\
\text { on }\end{array}$ & $\begin{array}{l}\mathbf{C} \\
\mathbf{E}\end{array}$ & $\begin{array}{l}\text { Transiti } \\
\text { on }\end{array}$ & $\begin{array}{l}\mathbf{C} \\
\mathbf{E}\end{array}$ \\
\hline Aldrin & Organochlorine & $\begin{array}{l}263.0-> \\
191.0\end{array}$ & 40 & $\begin{array}{l}298.0-> \\
263.0\end{array}$ & 8 \\
\hline Azoxystrobine & Strobilurin & $\begin{array}{l}344.0-> \\
329.0\end{array}$ & 15 & $\begin{array}{l}344.0-> \\
210.0\end{array}$ & 30 \\
\hline $\begin{array}{l}\text { BHC alpha } \\
\text { isomer }\end{array}$ & Organochlorine & $\begin{array}{l}181.0-> \\
145.0\end{array}$ & 30 & $\begin{array}{l}181.0-> \\
109.0\end{array}$ & 20 \\
\hline $\begin{array}{l}\text { BHC beta } \\
\text { isomer }\end{array}$ & Organochlorine & $\begin{array}{l}181.0-> \\
145.0\end{array}$ & 20 & $\begin{array}{l}181.0-> \\
109.0\end{array}$ & 20 \\
\hline Bifenthrin & Pyrethroids & $\begin{array}{l}181.1-> \\
165.1\end{array}$ & 30 & $\begin{array}{l}181.2-> \\
166.2\end{array}$ & 15 \\
\hline Chlordane, cis- & Organochlorine & $\begin{array}{l}372.7-> \\
266.1\end{array}$ & 25 & $\begin{array}{l}272.0-> \\
237.0\end{array}$ & 16 \\
\hline $\begin{array}{l}\text { Chlordane, } \\
\text { trans- }\end{array}$ & Organochlorine & $\begin{array}{l}272.0-> \\
237.0\end{array}$ & 16 & $\begin{array}{l}375.0-> \\
268.0\end{array}$ & 25 \\
\hline Chlorfenapyr & Pyrroles & $\begin{array}{l}408.0-> \\
59.0\end{array}$ & 10 & $\begin{array}{l}247.0-> \\
200.0\end{array}$ & 25 \\
\hline Chlorpyrifos & $\begin{array}{l}\text { Organophospha } \\
\text { te }\end{array}$ & $\begin{array}{l}196.9-> \\
168.9 \\
\end{array}$ & 15 & $\begin{array}{l}196.9-> \\
107.0\end{array}$ & 40 \\
\hline $\begin{array}{l}\text { Chlorpyrifos } \\
\text { Methyl }\end{array}$ & $\begin{array}{l}\text { Organophospha } \\
\text { te }\end{array}$ & $\begin{array}{l}288.0-> \\
93.0 \\
\end{array}$ & 25 & $\begin{array}{l}286.0-> \\
271.0\end{array}$ & 20 \\
\hline Cyfluthrin & Pyrethroids & $\begin{array}{l}198.9-> \\
170.1\end{array}$ & 25 & $\begin{array}{l}162.9-> \\
127.0\end{array}$ & 5 \\
\hline $\begin{array}{l}\text { Cyhalothrin(- } \\
\text { lamda) }\end{array}$ & Pyrethroids & $\begin{array}{l}181.1-> \\
152.0\end{array}$ & 30 & $\begin{array}{l}181.1-> \\
127.1\end{array}$ & 35 \\
\hline Cypermethrin & Pyrethroids & $\begin{array}{l}181.1-> \\
152.1 \\
\end{array}$ & 30 & $\begin{array}{l}181.1-> \\
127.1\end{array}$ & 35 \\
\hline DDD, o,p'- & Organochlorine & $\begin{array}{l}235.0^{->} \\
165.0\end{array}$ & 25 & $\begin{array}{l}235.0-> \\
199.1\end{array}$ & 20 \\
\hline DDD, p,p' & Organochlorine & $\begin{array}{l}234.9-> \\
165.1 \\
\end{array}$ & 15 & $\begin{array}{l}235.0-> \\
199.1 \\
\end{array}$ & 15 \\
\hline DDT-o,p & Organochlorine & $\begin{array}{l}234.9-> \\
165.1 \\
\end{array}$ & 15 & $\begin{array}{l}235.0-> \\
199.1\end{array}$ & 15 \\
\hline DDE, o,p'- & Organochlorine & $\begin{array}{l}246.0-> \\
176.0\end{array}$ & 30 & $\begin{array}{l}246.0-> \\
211.0\end{array}$ & 20 \\
\hline DDE, p,p'- & Organochlorine & $\begin{array}{l}318.0-> \\
248.0 \\
\end{array}$ & 30 & $\begin{array}{l}246.0-> \\
211.0 \\
\end{array}$ & 20 \\
\hline DDT, p,p'- & Organochlorine & $\begin{array}{l}237.0-> \\
165.0 \\
\end{array}$ & 20 & $\begin{array}{l}235.0-> \\
199.1\end{array}$ & 20 \\
\hline Deltamethrin & Pyrethroids & $\begin{array}{l}181.0-> \\
152.0\end{array}$ & 25 & $\begin{array}{l}181.0-> \\
127.1\end{array}$ & 25 \\
\hline Diazinon & $\begin{array}{l}\text { Organophospha } \\
\text { te }\end{array}$ & $\begin{array}{l}179.1-> \\
137.2 \\
\end{array}$ & 20 & $\begin{array}{l}179.1-> \\
121.1 \\
\end{array}$ & 40 \\
\hline Dieldrin & Organochlorine & $\begin{array}{l}263.0-> \\
191.0 \\
\end{array}$ & 35 & $\begin{array}{l}263.0-> \\
193.0 \\
\end{array}$ & 40 \\
\hline $\begin{array}{l}\text { Endosulfan } \\
\text { sulphate }\end{array}$ & Organochlorine & $\begin{array}{l}271.9-> \\
236.9\end{array}$ & 20 & $\begin{array}{l}271.9-> \\
116.9 \\
\end{array}$ & 40 \\
\hline Endosulfan_alfa & Organochlorine & $\begin{array}{l}207.0-> \\
172.0 \\
\end{array}$ & 15 & $\begin{array}{l}194.9-> \\
160.0 \\
\end{array}$ & 5 \\
\hline Endosulfan_beta & Organochlorine & $\begin{array}{l}207.0-> \\
172.0 \\
\end{array}$ & 15 & $\begin{array}{l}238.8-> \\
204.0 \\
\end{array}$ & 15 \\
\hline Endrine & Organochlorine & $\begin{array}{l}263.0-> \\
193.0 \\
\end{array}$ & 40 & $\begin{array}{l}263.0-> \\
191.0 \\
\end{array}$ & 35 \\
\hline Fenitrothion & $\begin{array}{l}\text { Organophospha } \\
\text { tes }\end{array}$ & $\begin{array}{l}277.1-> \\
109.0 \\
\end{array}$ & 20 & $\begin{array}{l}277.0-> \\
260.0 \\
\end{array}$ & 5 \\
\hline Fenvalerate & Pyrethroids & $\begin{array}{l}167.0-> \\
125.1\end{array}$ & 15 & $\begin{array}{l}181.0-> \\
152.0\end{array}$ & 25 \\
\hline Heptachlor & Organochlorine & $\begin{array}{l}271.9-> \\
236.8\end{array}$ & 25 & $\begin{array}{l}272.1-> \\
143.0\end{array}$ & 50 \\
\hline HeptExoEpoxid & Organochlorine & $\begin{array}{l}183.0-> \\
155.0 \\
\end{array}$ & 20 & $\begin{array}{l}183.0-> \\
118.9 \\
\end{array}$ & 30 \\
\hline HeptOpoxid_B & Organochlorine & $\begin{array}{l}353.0-> \\
263.0\end{array}$ & 25 & $\begin{array}{l}353.0-> \\
282.0\end{array}$ & 20 \\
\hline $\begin{array}{l}\text { Hexachlorobenz } \\
\text { ene }\end{array}$ & Organochlorine & $\begin{array}{l}283.9-> \\
213.9 \\
\end{array}$ & 35 & $\begin{array}{l}283.9-> \\
248.8 \\
\end{array}$ & 25 \\
\hline Methoxychlor & Organochlorine & $\begin{array}{l}227.0-> \\
141.1 \\
\end{array}$ & 40 & $\begin{array}{l}227.0-> \\
169.0 \\
\end{array}$ & 30 \\
\hline Mirex & Organochlorine & $\begin{array}{l}272.0-> \\
237.0\end{array}$ & 20 & $\begin{array}{l}272.0-> \\
235.0\end{array}$ & 25 \\
\hline Permethrin & Pyrethroids & $\begin{array}{l}183.1-> \\
168.1 \\
\end{array}$ & 15 & $\begin{array}{l}183.1-> \\
153.1 \\
\end{array}$ & 10 \\
\hline $\begin{array}{l}\text { Pirimiphos- } \\
\text { methyl }\end{array}$ & $\begin{array}{l}\text { Organophospha } \\
\text { te }\end{array}$ & $\begin{array}{l}290.0-> \\
125.0\end{array}$ & 25 & $\begin{array}{l}290.0-> \\
233.0\end{array}$ & 10 \\
\hline Tebuconazol & Triazole & $\begin{array}{l}250.2-> \\
127.1\end{array}$ & 25 & $\begin{array}{l}250.2-> \\
125.0\end{array}$ & 25 \\
\hline
\end{tabular}

\begin{tabular}{llllll}
\hline \hline Tefluthrin, cis- & Pyrethroids & $\begin{array}{l}177.0-> \\
127.0\end{array}$ & 15 & $\begin{array}{l}177.0-> \\
137.0\end{array}$ & 15 \\
\hline \multirow{2}{*}{ Vinclozolin } & Organochlorine & $\begin{array}{l}212.0-> \\
172.0\end{array}$ & 15 & $\begin{array}{l}212.0-> \\
109.0\end{array}$ & 40 \\
\hline \hline
\end{tabular}

\section{RESULTS AND DISCUSSION}

The analysed samples showed that pesticide residues in lettuce were under the maximum residues level and $86 \%$ of them were below the limit of quantification. Only in 1 out of 34 lettuce samples was found Chlorpyrifos $(0.048 \mathrm{mg} \mathrm{kg}-1)$ near the MRL value of $0.05 \mathrm{mg} \mathrm{kg}-1$ as published in the "EU Pesticides database" [11]. Active substances found in lettuce were Chlorpyrifos, Lamda cyhalothrin and Deltamethrin. Chlorpyrifos was the most frequent pesticides among the organophosphates class. The last two active substances have been found sporadically in a few samples. Table No. 2 shows results of pesticide residues, expressed in percentages, for two commodities: grape and lettuce.

TABLE II:PRESENCE OF PESTICIDE RESIDUES IN GRAPE AND LETTUCE SAMPLES

\begin{tabular}{cccc}
\hline \hline Samples & $\begin{array}{c}\text { Residues level } \leq \\
\text { RL (\%) }\end{array}$ & $\begin{array}{c}\text { Sample residues } \\
\leq \text { MRL }(\%)\end{array}$ & $\begin{array}{c}\text { Sample residues } \\
>\text { MRL }(\%)\end{array}$ \\
\hline Grape & 51 & 30 & 19 \\
Lettuce & 86 & 14 & 0 \\
\hline \hline
\end{tabular}

Instrumental analysis was run by Agilent gas chromatograph with mass spectrometer. Analytes were separated in a HP-5 MS (30 m x $250 \mu \mathrm{m} \times 0.2 \mu \mathrm{m})$. Mass spectrometer was operating in Electron Ionization (EI) mode, the electron energy was $70 \mathrm{eV}$ and the temperature source was at $290^{\circ} \mathrm{C}$. The injector operating conditions were as follows: the injected volume was $1 \mu \mathrm{l}$; the initial oven condition was $50^{\circ} \mathrm{C}$ for 0.6 minutes following by a temperature increase up to $180^{\circ} \mathrm{C}$ at a rate of $15^{\circ} \mathrm{C} / \mathrm{min}$ held for one minute; then the temperature was increased at $230^{\circ} \mathrm{C}$ by $7^{\circ} \mathrm{C} / \mathrm{min}$ and in the end was up to $280{ }^{\circ} \mathrm{C}$ by $3{ }^{\circ} \mathrm{C} / \mathrm{min}$. All the analyses were performed in MRM mode. A typical chromatogram of Cypermethrin, Lambda cyhalothrin and Chlorpyrifos is shown in the figure below. In the middle there is a chromatogram of negative grape sample.

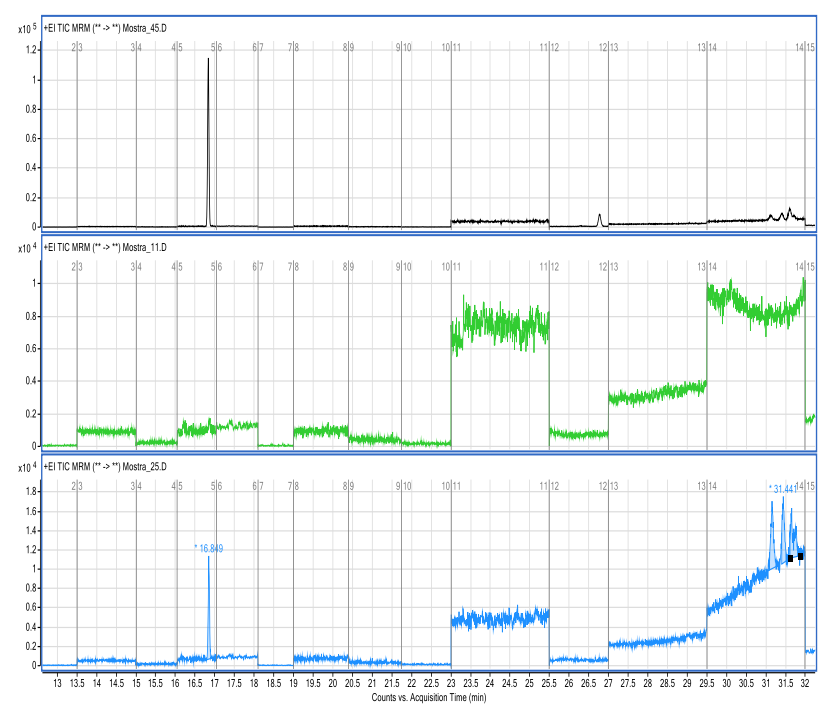

Fig. 1. Typical GC/MS/MS chromatogram of Cypermethrin, Lambda Cyhalothrin, Chlorpyrifos and a negative sample 
According to organochlorine and organophosphate pesticide no pesticides were found from this group. Because of their persistence on environment and harmful effects on human health these pesticides are restricted in many countries. There are few studies on pesticide residues in soil and plants in our country, but recently an important study that includes mostly agricultural land with biological production destination, has shown that except for some cases, the presence of DDT residues may be related to their previous use and not to new inputs after they were banned. This study concluded that the presence of persistent organic pesticides residues was over $10 \mu \mathrm{gKg}^{-1}$ in $40 \%$ of soil samples [12]. However, in grape and lettuce samples the presence of persistent organic pesticides was not identified.

\section{CONCLUSION}

- Grape samples contain residues exceeding the MRL in $19 \%$ of them

- Chlorpyrifos is the most active substance in grape found up than $0.05 \mathrm{mg} \mathrm{kg}-1$.

- While the lettuce residues were all below the MRL for each pesticide residues.

- The presence of residues in grape sample may be the attribute of not following the correct integrated pest management practices and pre-harvest time of the farmer and may pose a risk to human health.

\section{REFERENCES}

[1] W. J. Ntow, (2008). The use and fate of pesticide in vegetables-based agroecosystems in Ghana". Netherlands: Taylor \& Francis/Balkema.

[2] S. D. Grimalt., (January 2016). "Review of analytical methods for the determination of pesticideresidues in grapes" Journal of Chromatography A, pp. 1-28.

[3] R. P. Hlihor, (2016). Human Health Risk Assessment of Pesticide Residues in Field Grown Yellow Peppers". International Proceedings of Chemical, Biological and Environmental Engineering, Volume 94 of IPCBEE, 32-37.

[4] S. M. Elgueta (2017). "Pesticide residues in leafy vegetables and human health risk assessment in North Central agricultural areas of Chile". Food Additives \& Contaminants, pp. 1-8.

[5] 2009/128/EC, C. (2009). Directive 2009/128/ec of the european parliament and of the council of 21 October 2009 establishing a framework for Community action to achieve the sustainable use of pesticides. Official Journal of the European Union, L309/71-L309/86.

[6] M. M. Hero (2017, October 5-7 ). Dietary risk assessment of pesticide residues in bananas. Journal of Hygienic Engineering and Design, pp. 61-65.

[7] M. Cara,V. Vorpi.V. Vladi 2011). Degradation of the Insecticide Acetamiprid in Greenhouse Cucumbers and an Estimation of the Level of Residues. Journal of Environmental Protection and Ecology, 74-80.

[8] Lechenet M., D. F. (2017). Reducing pesticide use while preserving crop productivity and profitability on arable farms . Nature plants, https://www.nature.com/articles/nplants20178.

[9] NCFA, N. C. (2013). Pesticide residues analysis in foods with ethyl acetate extraction using gas and liquid chromatography with tandem mass spectrometric determination. N0 192

[10] 2002/63/EC. (2002). Commission Directive of 11 July 2002 establishing Community methods of sampling for the official control of pesticide residues in and on products of plant and animal origin and repealing Directive 79/700/EEC.

[11] Commision, E. (2018). EU Pesticides database. Retrieved from http://ec.europa.eu/food/plant/pesticides/eu-pesticidesdatabase/public/?event=activesubstance. selection\&language $=\mathrm{EN}$.

[12] M.Mukaj (2018). Vlerësimi i mbetjeve të pesticideve ndotës organikë të qëndrueshëm në tokat bujqësore, në kuadër të kontrollit dhe prodhimit biologjik. 